\title{
Bio-oil yield potential of some tropical woody biomass
}

\author{
Edmund C Okoroigwe ${ }^{1,2}$
}

Zhenglong $\mathrm{Li}^{3}$

\section{Shantanu Kelkar ${ }^{3}$}

Christopher Saffron ${ }^{3}$

\section{Samuel Onyegegbu ${ }^{2}$}

1. National Centre for Energy Research and Development, University of Nigeria, Nsukka, Nigeria

2. Department of Mechanical Engineering, University of Nigeria, Nsukka, Nigeria

3. Department of Biosystems and Agricultural Engineering, Michigan State University, East Lansing, USA

\begin{abstract}
Six tropical biomass samples namely: Ogbono wood (Irvingia wombolu), Mango wood (Mangifera indica), Neem wood (Azadiracta indica), Ogbono shell (Irvingia wombolu), Ogirisi wood (Neubouldia laevis) and Tropical Almond wood (Terminalia catappa) were pyrolyzed in a bench scale screw reactor at $450 \mathrm{oC}$. The physicochemical properties of the samples were determined prior to the pyrolysis experiments. The bio-oil and bio-char produced were similarly characterized using standard procedures established by American Standard and Test Methods (ASTM). The highest bio-oil yield of 66 $w t \%$ and least bio-oil yield of $53 w t \%$ were obtained from Neem wood and Tropical Almond wood respectively. The characterization results of the products show that even though the moisture content of the bio-oil was quite higher than those of the original feedstock, their higher heating values were higher than those of the parent feedstock. Both characterization results show that the feedstock and their fast pyrolysis products are good materials for bioenergy production. The Gas Chromatography Mass Spectroscopy (GC-MS) analysis of the bio-oil shows the presence of useful chemicals such as phenols and levoglucosan, which could be harnessed for industrial applications.
\end{abstract}

Keywords: biomass, pyrolysis, bio-oil, characterization, energy, bio-char

\section{Introduction}

The rapid degradation of the environment due to climatic changes resulting from huge consumption of fossil fuels has led to the search and advocacy of biomass-based fuels as alternative or blend to fossil fuels thereby reducing the fossil fuel consumption gross index. The geographical spread of biomass vis-à-vis natural gas, oil and coal is a support for encouraging the use of biomass for energy production.

Biomass fast pyrolysis is one of the sources of the biofuels regarded as future generation fuels which are suitable for the environment (Dinesh et al., 2006, Bui et al., 2009, Sivakumar et al., 2010). Pyrolysis is the intermediate process in both combustion and gasification technologies involved in biomass to energy conversion. Knowledge of the pyrolysis characterization of biomass materials and their products are very important in the design of any conversion technology systems as well as a guide to selecting most suitable species for biofuel production from the biomasses (Tsamba et al., 2006). Hence, the characterization of the parent feedstock is fundamental in pyrolysis technology. It is usually more cost effective to transport the fast pyrolysis products than transporting the bulk biomass from one place to the other compared to other conversion techniques.

Even though, virtually, every plant biomass can be pyrolyzed (Ingram et al., 2008) some species are more suitable than the others under the same technical and operational conditions. In tropical Africa, there are huge wastes resulting from low mecha- 
nized system of agriculture such as stalks, shells, shrubs or remains of felled trees and stumps. These are commonly burnt in the open as part of a land clearing method (Senjobi et al., 2007, Pantami et al., 2010) to give way to farm operations. Similarly, logs of wood in the forest are hewed for fuelwood or burnt in the open (when dry) to make way for other uses of the forest. Wood shavings and sawmill wastes are similarly burnt as a way of disposing them (Azeez et al., 2010). These contribute to the ranking of Africa as leader in biomass burning emission source (Andreae, 1991; Roberts, 2008). The emissions from the burning contribute to the climatic problems confronting our environment. If Africa's huge biomass potential is adequately utilized in bioenergy production, it will contribute immensely to the solution of global energy demand and economic problems of the developing nations.

The search for green energy has attracted a lot of interests in research, ranging from characterization of different biomass materials for their energy production potential (Satyanarayan et al., 2010; De Ramos et al., 2011), to actual production and upgrading of bioenergy-based products for fuel and chemical production. To date there is little or no evidence, in literature, of converting the tropical biomass species used in this work, to bioenergy. However, Azeez et al. (2010) pyrolyzed three tropical biomass materials - iroko (Chlophora excelsa L.), albizia (Albizia adianthifolia L.), and corncob (Zea mays ssp) obtained in Nigeria alongside two European species - spruce (Picea abies L.) and beech (Fagus sylvatica L), in a Fluidized Bed reactor and Py-GC/MS. In their work, the tropical biomass species showed some potential as sources of bioenergy and could compete favourably with temperate biomass species if pre-treatment operations such as removal of ash and extractives are carried out. In our work, six biomass species were characterized and pyrolyzed in a bench scale screw pyrolysis reactor with a view to determining their suitability for commercial bio-oil production. The products were characterized in order to determine their potential as sources of bioenergy. The pyrolysis of the biomass used in this work for bio-oil production and characterization has not been reported in literature to the knowledge of the authors.

\section{Experimental}

\subsection{Feedstock selection}

Six tropical woody biomass samples obtained within Nsukka urban and prepared at the National Centre for Energy Research and Development, University of Nigeria, Nsukka were used for the experiment. These include Ogbono wood (Irvingia wombolu), Mango wood (Mangifera indica), Neem wood (Azadiracta indica), Ogbono shell (Irvingia wombolu), Ogirisi wood (Neubouldia laevis) and Tropical Almond wood (Terminalia catappa).
Ogbono wood tree is deciduous and can be as old as 60 years before it can be felled for wood production. Usually the fruit is made of edible pulp and cartilaginous seed housed in a woody shell. In some regions it a common economic tree that grows uncultivated in large numbers owned by families. For this work the specimen was cut from the mature tree about 15 to 20 years together with its shell. Mango trees can be planted in large plantations as a commercial tree. The specimen for this research was obtained from one estimated to be up to 25 to 30 years old even though not from a commercial farm. In tropical Nigeria, mango trees can be planted individually near residential homes only to be felled when its presence poses a safety threat to buildings. The wood can only be useful as fuelwood for combustion purposes. It could constitute as an environmental nuisance if not burnt immediately.

A Neem tree in Nigeria serves as an ornamental and medicinal plant depending on the purpose of its cultivation and the part of the plant of interest. It can be as old as 45 years before aging depending on the soil conditions. It grows in large quantities even though there is no existing 'Neem farm' in our country. Like the mango wood it can only be used as fuelwood for combustion purposes when felled. The sample for this research is from a mature tree that is not less than 20 years of age. The Ogirisi tree and the Tropical Almond tree are wild plants which are not cultivated for economic purposes other than for local fencing and ornamental shade respectively. They are both soft woods that cannot be used for wood production for structural purposes. Because they are fast growing they produce large wood. The ones used for this research were obtained from species that are not more than 10 years old. The samples were cut, air dried and milled to a particulate size less than $1 \mathrm{~mm}$ passing mesh $40(425 \mu \mathrm{m})$ using Wiley milling machine.

\subsection{Feedstock characterization}

The physicochemical analyses of the feedstock were carried out to determine the properties of the feedstock prior to the bench scale pyrolysis. The properties analyzed include the: moisture content, percentage ash, higher heating values (HHV); compositional analysis (lignin and structural carbohydrates) and elemental composition analyses to determine $(\mathrm{C}, \mathrm{H}, \mathrm{N}, \mathrm{O}, \mathrm{S})$. The detailed procedures for these analyses are similar to those reported in (Okoroigwe et al., 2012).

\subsection{Pyrolysis experiment:}

The bench scale pyrolysis experiment was performed with the screw reactor (Figure 1). The system is made of a biomass delivery unit being powered by a 1.5 horse power $(\mathrm{Hp})$ electric motor and comprising: (1). The metering device (2), Made of a glass cylinder fitted into the $420 \mathrm{~mm}$ long stainless 


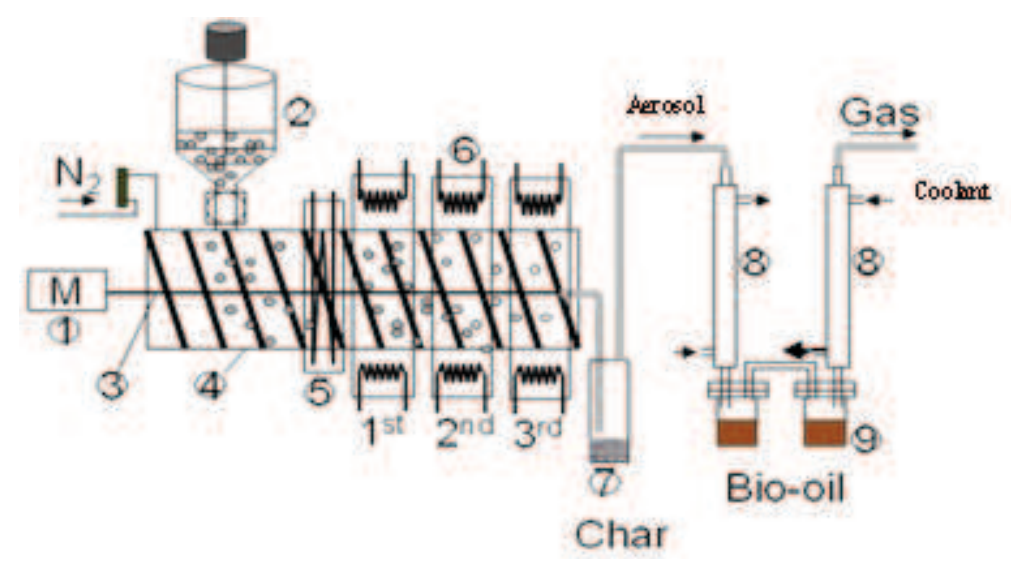

Figure 1: The schematic diagram of the reactor

steel barrel (4), housing the screw shaft (3). Nitrogen gas is delivered to the system on top of the hopper to ensure complete purging of air (oxygen) from the system before and during the pyrolysis process. The barrel is heated externally by six band heaters (6) of $750 \mathrm{~W}$ each, fixed on the barrel. There are 3 heating zones for the pyrolysis process. Two band heaters form a heating zone equally spaced along the $420 \mathrm{~mm}$ heated zone of the reactor and set to raise the temperature of the barrel to a fixed value. As the electric motor drives the shaft, the biomass is smeared on the hot barrel wall which decomposes the biomass. Since the barrel outer wall is heated, heat transfer to the shaft and inside wall is by conduction and slight convection because of trapped gas. To prevent backflow of heat from the nearest band heaters to the hopper base and to prevent preheating of the biomass, a cooling system (5) is introduced by continuous flow of running water forming the feed cooling system.

The products recovery system of the reactor comprises the heated char trap (7) and the shell and tube heat exchanger (8) used to condense the vapour into liquid bio-oil in the Bio-oil containers (9). After the thermal decomposition of the biomass, aerosol (comprising the char and vapour) formed travel together to the char trap where char separation takes place. The char trap was heated using heating tapes rated 570 and $430 \mathrm{~W}$ in order to avoid pre-condensation of the vapour in the char trap. The liquid bio-oil was obtained by rapid quenching of the temperature of the vapour from about $450^{\circ} \mathrm{C}$ to about $2^{\circ} \mathrm{C}$ or less as obtained in different experiments. This was possible because two bio-oil collection containers were used. Both containers were each connected to a heat exchanger. The two containers were however interconnected by small tubing such that the products not collected in the first container due to inability to condense are collected in the second tube at much reduced temperature. The flow of the refrigerant is counter-current to the flow of the aerosol. The non- condensable gas exits from the last container by means of gas delivery pipe. Most of the liquid products con- densed at the first condenser, while at much lower temperature a further liquid product was collected in the second condenser. The non-condensable gases were let out of the chamber by gas delivery tube and collected into gas trap bags for analysis with gas analysers. The exit gas temperature was monitored using k-type thermocouples at temperature 8 to $2^{\circ} \mathrm{C}$. When tested for combustion, the mixture of gases burnt with blue flame implying the presence of flammable gases confirmed to be $\mathrm{H}_{2}$, $\mathrm{C}_{2} \mathrm{H}_{4}$, and $\mathrm{CH}_{4}$ by analysis of the gas using gas chromatographer.

\subsection{Products characterization}

The bio-oils were analysed for moisture and ash contents, density, $\mathrm{pH}$, elemental composition, viscosity, and heating values. They were also analysed using GC/MS for the determination of chemical compounds present in the oils. For the char, only the heating value and ash content were determined using bomb calorimeter and electric furnace methods respectively. The elemental analysis for determination of Carbon, Hydrogen, Nitrogen, Oxygen and Sulphur content of the bio-oil samples was performed at Galbraith Labs Inc, Knoxville, Tennessee USA. The ASTM D5291-02 (Standard Test Methods for Instrumental Determination of Carbon, Hydrogen, and Nitrogen in Petroleum Products and Lubricants) and the LECO CHN 2000 analyser were used as standard procedure and instrumentation respectively. Oxygen was determined by difference while Sulphur was determined according to ASTM D4239-83 using LECO SC-432DR (Trace E16-2A). The water content of the liquid product was determined by Karl Fischer titration method according to ASTM E203 at the Galbraith labs.

\section{Results and discussion \\ 3.1 Feedstock characterization}

The results of the characterization of the feedstock used in the pyrolysis experiments are presented in Table 1 . The table contains the proximate (physical properties) and ultimate analyses results. 
Table 1: Feedstock characterization

\begin{tabular}{|c|c|c|c|c|c|c|c|c|}
\hline \multicolumn{2}{|l|}{ Property } & Base & $\begin{array}{l}\text { Ogbono } \\
\text { wood }\end{array}$ & $\begin{array}{c}\text { Mango } \\
\text { wood }\end{array}$ & $\begin{array}{l}\text { Neem } \\
\text { wood }\end{array}$ & $\begin{array}{l}\text { Ogbono } \\
\text { shell }\end{array}$ & $\begin{array}{l}\text { Ogirisi } \\
\text { wood }\end{array}$ & $\begin{array}{c}\text { Tropical almond } \\
\text { wood }\end{array}$ \\
\hline \multirow[t]{6}{*}{ Physical } & \multicolumn{2}{|c|}{ Moisture content (\%) } & 6.27 & 4.83 & 6.83 & 7.70 & 6.42 & 7.62 \\
\hline & \multirow{3}{*}{ HHV MJ/kg) } & ar & 20.01 & 22.23 & 18.71 & 20.20 & 20.69 & 20.50 \\
\hline & & $\mathrm{db}$ & 21.34 & 23.35 & 20.08 & 21.88 & 22.10 & 22.19 \\
\hline & & daf & 21.61 & 23.60 & 20.35 & 22.10 & 22.60 & 22.40 \\
\hline & \multirow[t]{2}{*}{ Ash (\%) } & ar & 1.14 & 0.98 & 1.22 & 0.91 & 2.06 & 0.88 \\
\hline & & $\mathrm{db}$ & 1.22 & 1.03 & 1.32 & 0.99 & 2.21 & 0.96 \\
\hline \multirow[t]{4}{*}{ Ultimate analysis } & $\mathrm{C}(\%)$ & & 45.94 & 46.39 & 45.86 & 47.62 & 46.00 & 45.86 \\
\hline & $\mathrm{H}(\%)$ & $\mathrm{Ar}$ & 6.11 & 6.27 & 6.36 & 6.34 & 6.50 & 6.36 \\
\hline & & $\mathrm{db}$ & 5.73 & 5.97 & 5.93 & 5.85 & 6.08 & 5.88 \\
\hline & $\mathrm{N}(\%)$ & & $<0.50$ & $<0.50$ & $<0.50$ & $<0.50$ & $<0.60$ & $<0.50$ \\
\hline \multicolumn{3}{|c|}{$\mathrm{O}(\%)$ (by difference) } & 44.64 & 45.19 & 45.34 & 44.03 & 44.04 & 45.34 \\
\hline \multicolumn{3}{|c|}{$\mathrm{S}(\%)$} & $<0.50$ & $<0.50$ & $<0.50$ & $<0.50$ & $<0.50$ & $<0.50$ \\
\hline \multicolumn{3}{|c|}{$\mathrm{O}: \mathrm{C}$} & 0.97 & 0.97 & 0.99 & 0.92 & 0.96 & 0.99 \\
\hline \multicolumn{3}{|c|}{$\mathrm{H}: \mathrm{C}$} & 0.13 & 0.14 & 0.14 & 0.13 & 0.14 & 0.14 \\
\hline
\end{tabular}

Note: $\mathrm{ar}=$ as received, $\mathrm{db}=$ dry basis, $\mathrm{daf}=$ dry and ash free

Table 1 shows the levels of moisture present in the samples at the time the experiments were carried out. There was varying moisture as expected, since wood samples have different cellular structure. It is obvious that moisture affects heating values of biomass samples (Demirbas, 2007), hence the variation in heating values of the samples 'on as received' basis. But on moisture fee (dry basis)', mango wood has the highest heating value of $23.35 \mathrm{MJ} / \mathrm{kg}$ while Neem wood has the lowest heating value of approximately $20.1 \mathrm{MJ} / \mathrm{kg}$.

On an ash free basis, the lower heating value of mango wood appears to be highest even though its ash content is not lower than that of Tropical Almond wood. It has been shown that ash in biomass has a dominant effect on bio-oil yield and composition (Azeez et al., 2010; Brown, 2011). Removal of ash and extractives in pre-treatment steps prior to pyrolysis improves the quality of biooil (Das et al., 2004). This implies that Tropical Almond wood with $0.88 \%$ ash content is a better option than the rest in terms of bio-oil yield and quality. But this does not agree with the result presented in Table 2, where Neem wood yielded 66 wt\% of bio-oil followed by mango wood even though their ash contents are slightly higher than that of Tropical Almond wood. Since ash content is not the only factor determining the percentage bio- oil yield, there could be other conditions favouring the yield of bio-oil in one biomass than the others in this experiment.

The hydrogen to carbon ratio $(\mathrm{H}: \mathrm{C})$ and oxygen to carbon ratio $(\mathrm{O}: \mathrm{C})$ are good parameters to evaluate energy potential of biomass. It appears that all the biomass species are good feedstock for energy production by considering their $\mathrm{H}: \mathrm{C}$ and $\mathrm{O}: \mathrm{C}$ ratios with the later close to 1 . The result of the composition analysis of the lignocelluloses is presented in Figure 2. Comparatively, all the biomass species are rich in cellulose and lignin. The percentage composition of cellulose is not less than $35 \%$, while lignin is between 20 and $35 \%$. The maximum value of hemicelluloses $(18 \%)$ occurred in ogirisi wood, while the least $(8 \%)$ occurred in ogbono shell. The biomass materials were not pre-analysed for extractives; hence the 'difference' could represent inorganic materials in form of extractives. The large value of this component is in agreement with Azeez et al. (2010) who asserted that tropical species are richer in extractives than European biomass species. The extractives are made up of phenolic compounds, terpenes, aliphatic acids, chinones and alcohols. High content of these components often results in low polyoses content in wood. These could be responsible for the chemicals present in the bio-oil as presented in Table 3 .

Table 2: Pyrolysis experiment results

\begin{tabular}{lcccccc}
\hline Parameter & $\begin{array}{c}\text { Ogbono } \\
\text { wood }\end{array}$ & $\begin{array}{c}\text { Mango } \\
\text { wood }\end{array}$ & $\begin{array}{c}\text { Neem } \\
\text { wood }\end{array}$ & $\begin{array}{c}\text { Ogbono } \\
\text { shell }\end{array}$ & $\begin{array}{c}\text { Ogirisi } \\
\text { wood }\end{array}$ & $\begin{array}{c}\text { Tropical almond } \\
\text { wood }\end{array}$ \\
\hline Bio-oil yield (wt \%) & 60 & 61 & 66 & 58 & 57 & 53 \\
\hline Bio-char yield (wt \%) & 19 & 22 & 15 & 19 & 17 & 19 \\
\hline NCG (wt \%) by difference & 21 & 17 & 19 & 23 & 26 & 28 \\
\hline
\end{tabular}


Table 3: Chemical components of the bio-oil (area \%) on chromatograms

\begin{tabular}{lcccccc}
\hline Compound & \multicolumn{7}{c}{ \% area by sample } \\
\hline & $\begin{array}{c}\text { Ogbono } \\
\text { wood }\end{array}$ & $\begin{array}{c}\text { Mango } \\
\text { wood }\end{array}$ & $\begin{array}{c}\text { Neem } \\
\text { wood }\end{array}$ & $\begin{array}{c}\text { Ogbono } \\
\text { shell }\end{array}$ & $\begin{array}{c}\text { Ogirisi } \\
\text { wood }\end{array}$ & $\begin{array}{c}\text { Tropical almond } \\
\text { wood }\end{array}$ \\
\hline Acetic acid & 23.18 & 24.06 & 27.7 & 29.58 & 30.68 & 22.99 \\
\hline Acetol & 12.92 & 10.63 & 14.7 & 14.93 & 13.87 & 10.86 \\
\hline 2,3-pentanedione & 2.85 & - & 4.11 & 3.63 & 3.53 & 2.74 \\
\hline 2,5-dimethyl-furan & 2.35 & - & 2.44 & 2.48 & 2.81 & 2.56 \\
\hline 3-methyl- 1,2-cyclopentanedione & 3.08 & 3.48 & 3.39 & 3.29 & 3.9 & 3.49 \\
\hline Guaiacol & 4.4 & 1.76 & 3.05 & 4.37 & 4.28 & 3.55 \\
\hline 2-methoxy-4-methyl-phenol & 4.25 & - & 1.84 & 4.01 & 2.66 & 3.12 \\
\hline 2,6-dimethoxy-phenol & 3.96 & 5.49 & 7.01 & 3.11 & 6.04 & 6.92 \\
\hline 2-methoxy-4-(1-propenyl)-phenol & 3.88 & 1.85 & 2.22 & 2.58 & 3.23 & 3.36 \\
\hline 1,2,4-trimethoxybenzene & 3.16 & 2.55 & 3.55 & 2.34 & 2.68 & 4.96 \\
\hline 3',5'-dimethoxyacetophenone & - & 2.68 & 2.10 & - & 2.29 & 2.40 \\
\hline Levoglucosan & 17.2 & 12.92 & 7.48 & 15.55 & 3.65 & 12.16 \\
\hline 2,6-dimethoxy-4-(2-propenyl)-phenol & 3.52 & 8.03 & 4.9 & 1.52 & 4.18 & 5.51 \\
\hline 4-hydroxy-3,5-dimethoxy-benzaldehyde & 2.44 & 3.66 & - & - & 2.83 & 2.13 \\
\hline
\end{tabular}

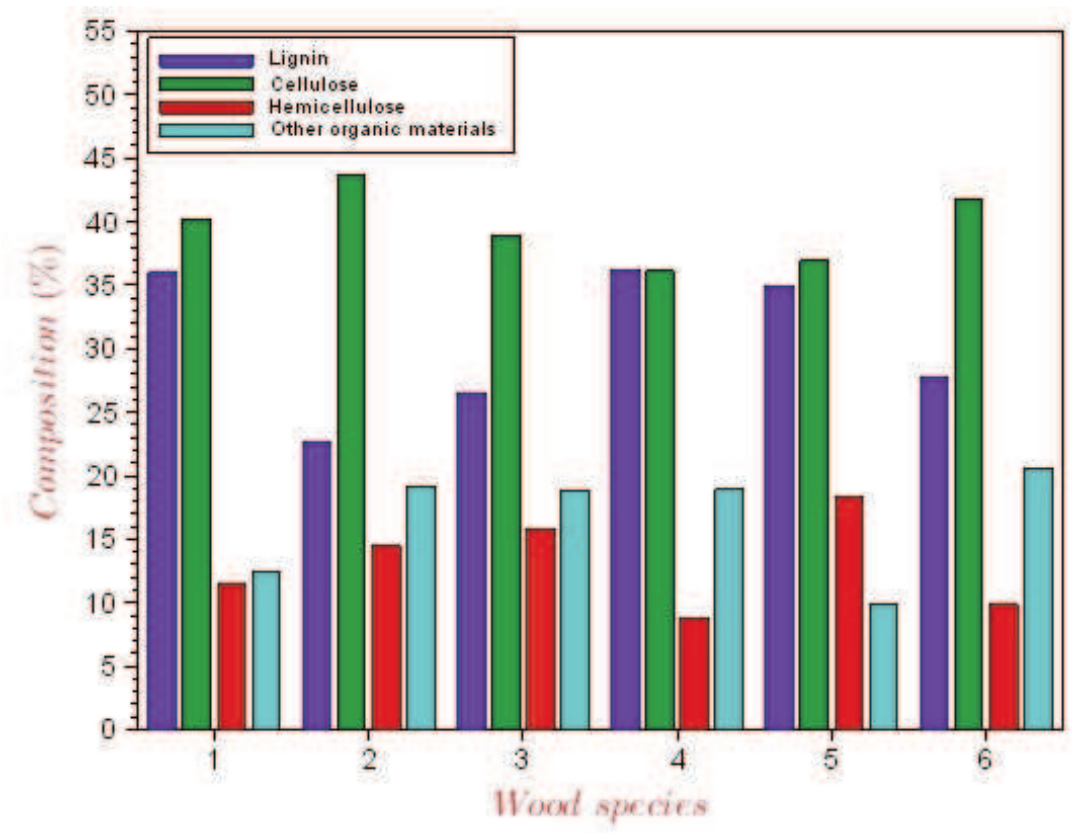

Figure 2: Structural carbohydrates and lignin composition

\subsection{Pyrolysis experiments}

Even though the experiments were carried out at different temperature, the operation temperature values were within the accepted range for maximum bio-oil production from fast pyrolysis experiments (Bayerbach et al., 2006; Bayerbach et al., 2009, Sulaiman and Abdullah, 2011). The mass balance of the bio-oil production is presented in Table 2 and shows that the highest bio-oil yield of $66 w t \%$ was obtained from Neem wood, while the least yield occurred in Tropical Almond wood. These values are close to that obtained by Azeez et al., (2010) even though a fluidized bed reactor was used at $470^{\circ} \mathrm{C}$. Meanwhile, the bio-oil \% yield of all the samples is greater than those obtained by Mullen and Boateng (2008) in the pyrolysis of switchgrass, early bud and full flower alfalfa in a $2.5 \mathrm{~kg} / \mathrm{hr}$ fluidized bed reactor at $500^{\circ} \mathrm{C}$.

However, the yields are lower than $75-80 \mathrm{wt} \%$ bio-oil proposed by Bridgwater (1999) on fast pyrolysis of wood. Higher bio-oil yield may be obtained under improved reactor and operating conditions. As many factors affect the yield of biooil, it may be very difficult to specifically peg certain factors as responsible for the variation in the quantity obtained from these species. Since more than $50 \%$ by weight of materials pyrolyzed are converted to bio-oil, then the species might be good enough for commercial bio-oil production. Even though the water content of the bio-oils from fast pyrolysis of these biomass species is high, their carbon and hydrogen content are high such that the 
Table 4: Some physical and chemical properties of the bio-oils

\begin{tabular}{lccccccccc}
\hline Bio-oil & $\begin{array}{c}\text { Density } \\
\left(\mathrm{g} / \mathrm{cm}^{3}\right)\end{array}$ & $\mathrm{pH}$ & $\begin{array}{c}\text { Viscosity } \\
@ 40^{\circ} \mathrm{C}(\mathrm{cp})\end{array}$ & $\begin{array}{l}\text { Water con- } \\
\text { tent }(\mathrm{wt} \%)\end{array}$ & & \multicolumn{3}{c}{ Elementalanalysis (wt \%) } \\
\hline Ogbono wood & & & & & $\mathrm{C}$ & $H$ & $\mathrm{O}$ & $\mathrm{N}$ & $S$ \\
\hline Mango wood & 1.08 & 2.87 & 13.7 & 34.76 & 44.73 & 7.42 & 43.83 & 0.66 & $<0.05$ \\
\hline Neem wood & 1.10 & 3.31 & 10.5 & 33.41 & 38.39 & 7.78 & 47.97 & 0.90 & $<0.05$ \\
\hline Ogbono shell & 1.11 & 2.80 & 17.4 & 29.99 & 39.68 & 7.42 & 49.66 & 1.25 & $<0.05$ \\
\hline Ogirisi wood & 1.05 & 2.88 & 5.7 & 36.82 & 37.83 & 7.96 & 41.93 & 0.70 & $<0.05$ \\
\hline Tropical Almond wood & 1.06 & 3.50 & 12.2 & 37.10 & 35.01 & 8.05 & 43.36 & 0.69 & $<0.05$ \\
\hline
\end{tabular}

fuels can combust well in boilers and engines. For high energy output the bio-oil from these species would need to undergo upgrading to improve their heating values.

\subsection{Products characterization}

\section{a) Bio-oil}

In order to achieve the desired quality of the bio-oils as sources of chemicals and fuel for power production, full characterization of the oils were carried out. Thus, Table 4 shows the elemental composition of the oils from the biomass samples. The table shows that the sulphur and nitrogen content of the oils were $\leq 0.05$ and 1.5 respectively. This implies that the combustion of the oils will result in emission of little or no sulphur and nitrogen related pollutants. The values of oxygen content of the bio-oils in this work are close and similar to those obtained in the bio-oil of other woody biomass samples such as presented by (Dinesh et al., 2006; Adisak et al., 2007; Uzun et al., 2010) but slightly higher than those of Ingram et al.(2008). The presence of $\mathrm{O}_{2}$ that is primarily responsible for the difference in the behaviour and properties of hydrocarbons and bio- mass liquid products such as bio-oils (Oasmaa and Czernik, 1999). In fact, it is rare to obtain bio-oil whose oxygen content is less than $30 \mathrm{wt} \%$. So, the values obtained in these tropical biomass samples are not out of place for a typical bio-oil. It is the presence of high oxygen and water content in the bio-oils, that the fuels are plagued by poor volatility, high viscosity (Table 4) and corrosiveness (Dinesh et al., 2006; Oasmaa and Czernik, 1999). The elemental composition of the bio-oils resembles those of the parent feedstock from where they are derived and differ significantly from petroleum oils. The presence of $\mathrm{O}_{2}$ and water in the biomass pyrolysis bio-oil may be responsible for the low pH values of the product as shown in Table 4. This agrees with the high value of acetic acid content of all the bio-oils shown in Table 3. The $\mathrm{pH}$ of heavy fuel oils is zero while that of bio-oil from wood pyrolysis can be as low as 2.5 (Dinesh et al., 2006), confirming the range of values $(2.8-3.5)$ obtained in this work. Similarly, the density $\left(\mathrm{gcm}^{-3}\right)$ and/or the specific gravity of the bio-oils (Table 4) are slightly above 1 which are typical of pyrolysis liquids but are higher than those of heavy fuel oil. This implies

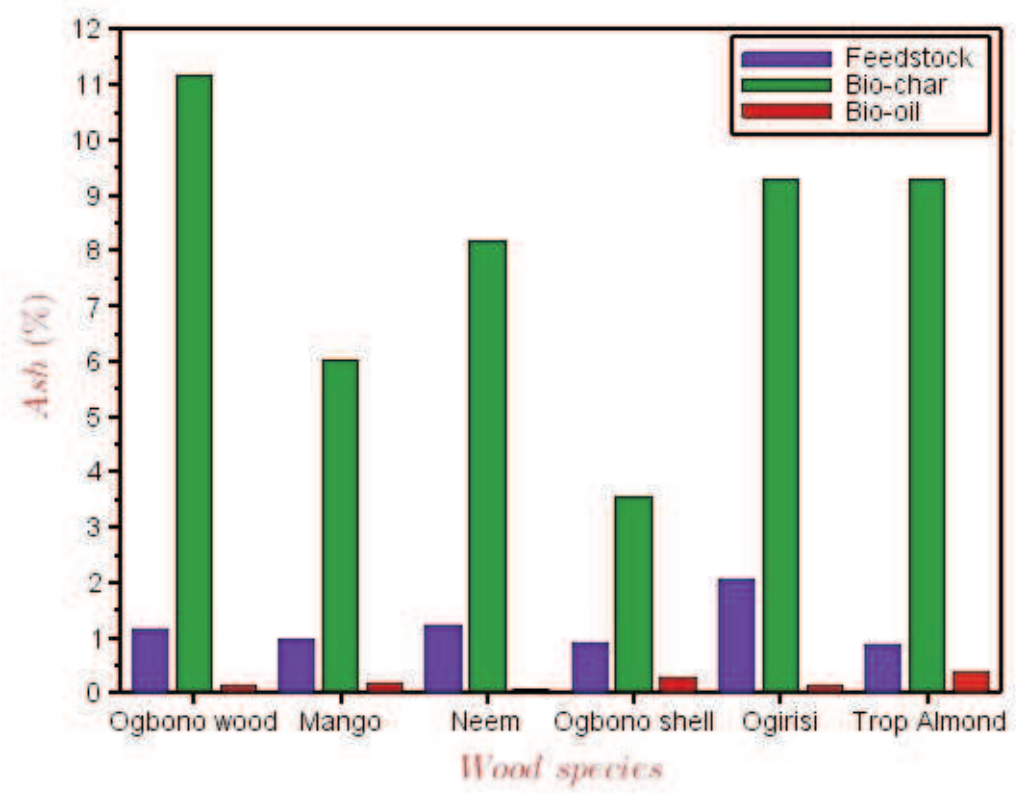

Figure 3: Ash content of feedstock and pyrolysis products

1: Ogbono wood, 2: Mango wood, 3: Neem wood, 4: Ogbono shell, 5: Ogirisi wood, 6:-Tropical Almond wood 


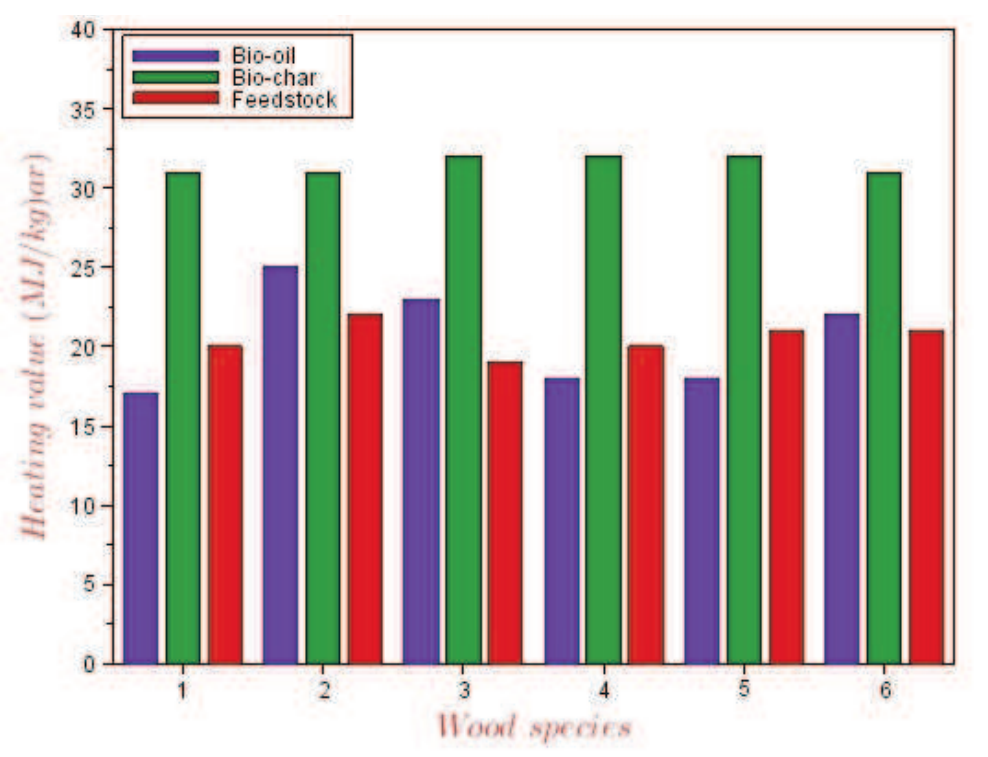

Figure 4: Heating value of feedstock and pyrolysis products

that the bio-oil from these tropical biomass samples can serve similar purposes which other non-tropical species have served.

The conversion of the biomass to bio-oil and char resulted in significant improvement in the quality of the products as fuel over the parent feedstock. Even though in Figure 3 the ash content of char increased over the values obtained for the raw feedstock, the heating values increased significantly (Figure 4), when compared with those for the feedstock. This implies increased energy value of the products (bio-oil, char and gas) vis-à-vis the raw feedstock.

\section{GC/MS analysis result}

The gas chromatography and mass spectrometry analysis of the bio-oils was carried out and Table 3 shows the composition by quantity (area \%) of major chemical compounds in the bio-oils. It also shows the summary of some of the major chemical compounds and their relative abundance ( $\%$ area) in the chromatographic analyses of the oils using GC/MS. The chemicals are similar to those identified by some researchers (Ingram et al., 2008; Czernik and Bridgwater, 2004; Sipila et al., 1998; Akwasi et al., 2007). This shows that the biomasses and their bio-oil products can be sources of valuable chemicals such as phenols used for industrial purposes. Conversion to bio-oil and char through pyrolysis instead of direct combustion is value addition to the materials as sources of chemicals and energy.

\section{b) Bio-char characterization}

Only the heating values and the ash contents were determined as shown in Figures 3 and 4 respectively. All the char products show significant potential to be used as sources of thermal energy in combustion chambers of boilers and combustors. The pyrolysis conversion of the feedstock produces high energy density fuel (bio-char) whose higher heating values are close to those of coal. Generally, it implies that the bio-char from these samples can supplement the energy input of the pyrolysis reaction through product recycling and thus reduces the energy input. Even though the elemental analyses of these bio-char products were not carried out to identify the sulphur and nitrogen content, insignificance presence of these elements in the parent feedstock shows that these bio-char could serve as environmentally friendly fuel.

\section{Conclusion}

The feedstock and their pyrolysis products possess the properties required for applying the pyrolysis technology to the conversion of the feedstock and products to energy. The bio-oil products and char can be utilized in power generation by combustion in boilers and thermal plants. If upgraded, better fuel quality will be obtained from the bio-oil products. The results of the GC/MS analysis of the biooils show that these products can be sources of useful industrial chemicals where the focus lies on chemical production. The wastes resulting in the cultivation or use of the feedstock, in daily socioeconomic activities of the tropical regions where they are largely produced, can be easily converted to useful energy through fast pyrolysis leading to improved lifestyle, better agricultural output and better environment. The use of these biomass species for energy and chemicals production through fast pyrolysis conversion is recommended.

\section{Acknowledgement}

This work was possible through the Fulbright Fellowship award $b$ thy International Institute of Education (IIE) to Edmund Okoroigwe as Visiting Scholar to Michigan State 
University, East Lansing and partly funded AgBioResearch at Michigan State University.

\section{References}

Adisak P, Titiloye J. O, and Bridgwater A. V. (2007). Fast Pyrolysis of Agricultural Residues from Cassava Plantation for Bio-oil production, Asian J Energy and Environ 8 (2): 496 - 502.

Akwasi B, Daugard D. E., Goldberg N. M, and Hicks K. B. (2007). Bench-Scale Fluidized Bed Pyrolysis of Switchgrass for Bio-oil Production, Ind Eng. Chem Res. (46) $1891-1897$.

Andreae M. O. (1991). In Global Biomass Burning: Atmospheric, Climatic and Biospheric Implications; Levine J.S., Ed.; MIT Press: Cambridge, MA pp 221.

Azeez A. M, Meier D, Odermatt J, and Willner T. (2010). Fast Pyrolysis of African and European Lignocellulosic Biomasses Using Py-GC/MS and Fluidized Bed Reactor, Energy Fuels 24: 2078-85: DOI: 10.1021/ef9012856.

Bayerbach R. and Meier DJ. Characterization of the water-insoluble fraction from fast pyrolysis liquids (pyrolytic lignin). Part IV: Structure elucidation of oligomeric molecules, Anal. Appl. Pyrolysis 2009, 85: 98- 107. In [Azeez et al., 2010].

Bayerbach R, Nguyen V. D, Schurr U, and Meier D. J. (2006). Characterization of the water-insoluble fraction from fast pyrolysis liquids (pyrolytic lignin): Part III. Molar mass characteristics by SEC, MALDI-TOFMS, LDI-TOF-MS, and Py-FIMS Anal. Appl. Pyrolysis 2006, 77(2) 95-101. In [Azeez et al., 2010].

Bridgwater A. V. (1999). Principles and Practice of Biomass Fast Pyrolysis Processes for Liquids, Anal Appl Pyrolysis 51: 3-22.

Brown R. C. (Ed). (2011). Thermochemical processing of biomass. Conversion into fuels, chemical and power. Wiley publishers, $128-129$.

Bui V. N, Toussaint G, Laurenti D, Mirodatos C, and Geantet C. (2009). Co-processing of pyrolysis bio oils and gas oil for new generation of bio-fuels: Hydrodeoxygenation of guaïacol and SRGO mixed feed, Catalysis Today 143(1-2): 172 - 178.

Czernik S. and Bridgwater AV. (2004). Overview of Applications of Biomass Fast Pyrolysis Oil Energy Fuels 2004; 18:590-8. In [Adisak et al., 2007].

Das P, Ganesh A, and Wangikar P. (2004). Influence of pre-treatment for deashing of sugarcane bagasse on pyrolysis products. Biomass Bioenergy 27,445-457. In [Azeez et al., 2010].

De Ramos P. L. E, Trugilho P. F, Napoli A, and Bianchi M. L. (2011). Characterization of residues from plant biomass for use in energy generation, Revista Cerne, 17 (2): $237-246$.

Demirbas A. (2007). Effects of Moisture and Hydrogen Content on the Heating Value of Fuels. Energy Sources, Part A: Recovery, Utilization, and Environmental Effects; 29 (7). DOI: 10.1080/009083190957801.

Dinesh M, Pittman C.U Fr, and Steele P. H. (2006). Pyrolysis of wood/Biomass for Bio-oil: A critical Review, Energy Fuels 20: 848 - 889.
Ingram L, Dinesh M, Bricka M, Steele P, Strobel D, Croker D, Mitchell B, Mohammad J, Cantrell K, and Pittman C. U Jr. (2008). Pyrolysis of Wood and Bark in an Auger reactor: Physical properties and chemical Analysis of the produced bio-oils. Energy Fuels 22: $614-625$

Mullen A. C and Boateng A. A. (2008). Chemical Composition of Bio-oils Produced by Fast Pyrolysis of Two Energy Crops, Energy and Fuels 22: 2104 2109.

Oasmaa A, and Czernik S (1999). Fuel Oil Quality of Biomass Pyrolysis Oils State of the Art for the End Users. Energy Fuels 13:914 - 921. In [Adisak et al., 2007].

Okoroigwe E, Zhenglong L, Stuecken T, Saffron C, and Onyegegbu S. (2012). Pyrolysis of Gmelina arborea Wood for Bio-oil/Bio-char Production: Physical and Chemical Characterization of Products. J Appl Sc. 12(4): $369-374$.

Pantami S. A, Voncir N, Babaji G. A, and Mustapha S. (2010). Effect of Burning on Soil Chemical Properties in the Dry Sub-Humid Savanna Zone of Nigeria, Researcher 7: 78 - 83.

Roberts, G., Wooster, M. J., and Lagoudakis, E. (2009). Annual and diurnal African biomass burning temporal dynamics, Biogeosciences, 6, 849-866, doi: 10.5194/bg-6-849-2009.

Satyanarayan N, Vaibhav V. Goud P. K. Rout K. J, and Ajay K. D. (2010). Characterization of Canadian biomass for alternative renewable biofuel, Renew Energy 35(8), 1624-1631.

Senjobi B. A, Adeokun O. A, Dada O. A, and Ogunkunle A. O. (2007). Influence of Traditional Farming Practices on Soil Productive Potentials in Ago-Iwoye Enclave, Ogun State, Nigeria. J Environ Ext. 6: $64-70$.

Sipila K; Kuopala E, Fagernas L, and Oasmaa A. (1998). Characterization of Biomass-Based flash Pyrolysis Oils, Biomass Bioenergy 14 (2) 103 - 113

Sivakumar G, Vail D. R., Xu J, Burner D. M, Lay J. O, Ge X, and Weathers P. J. (2010). Bioethanol and biodiesel: Alternative liquid fuels for future generations, Eng. Life Sci., 10: 8-18. doi: $10.1002 /$ elsc.200900061.

Sulaiman F, and Abdullah N. (2011). Optimum conditions for maximizing pyrolysis liquids of oil palm empty fruit bunches, Energy 36: 2352 -2359.

Tsamba A. J, Yang W, and Blasiak W. (2006). Pyrolysis Characteristics and Global Kinetics of Coconut and Cashew nut shells. Fuel Proc Tech. 87:523 -30.

Uzun B. B, Apaydin-Varol E, Ates F, Ozbay N, and Putun A.(2010). Synthetic Fuel Production from tea waste: characterization of bio-oil and bio-char, Fuel 89: $176-184$.

Received 25 March 2014; revised 11 March 2015 
Appendix A: Pyrolysis experiments photographs

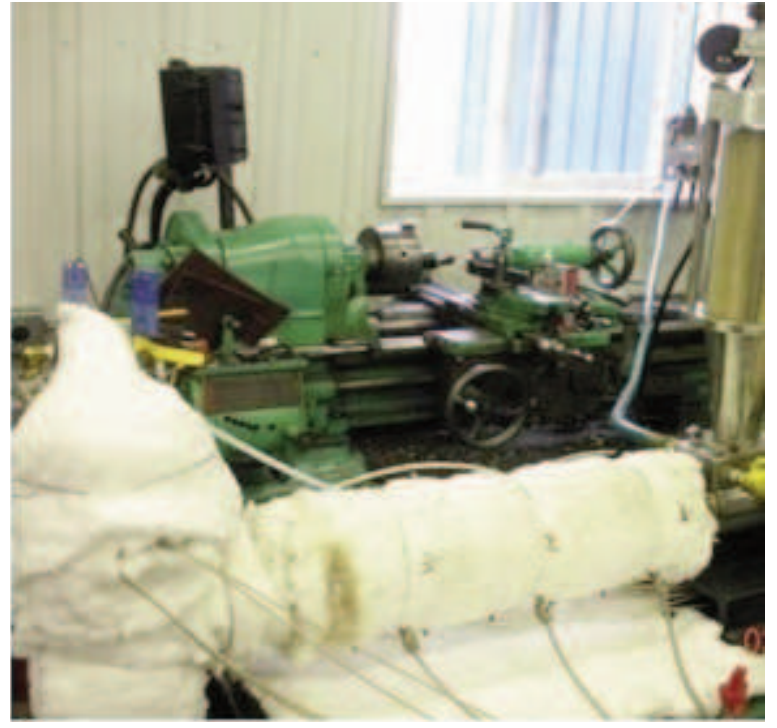

Figure A1: Reactor in use

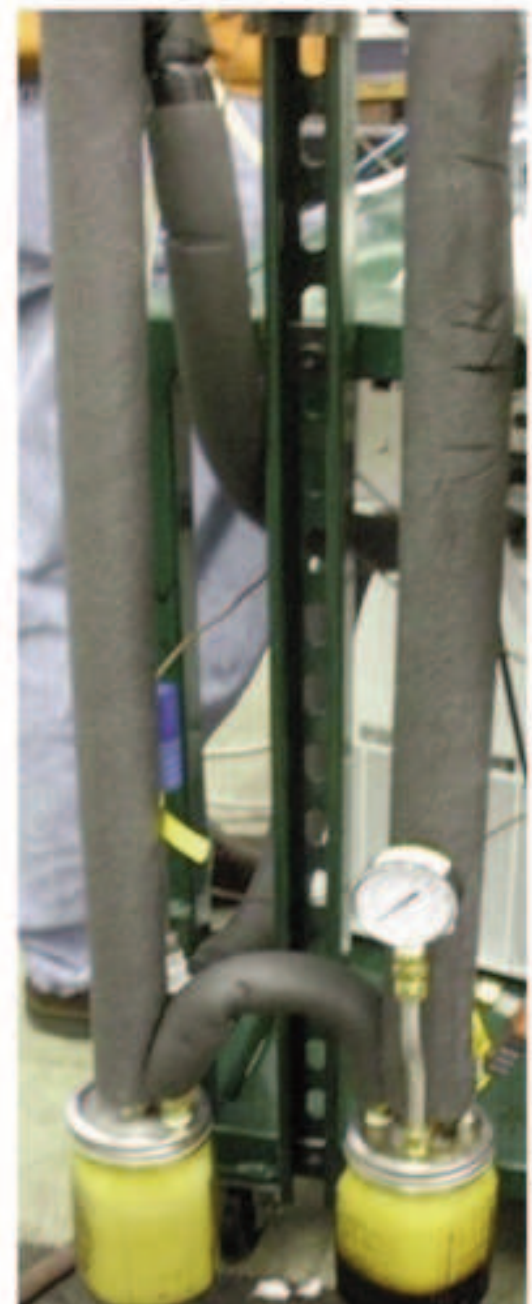

Figure A3: Bio-oil condensers and containers

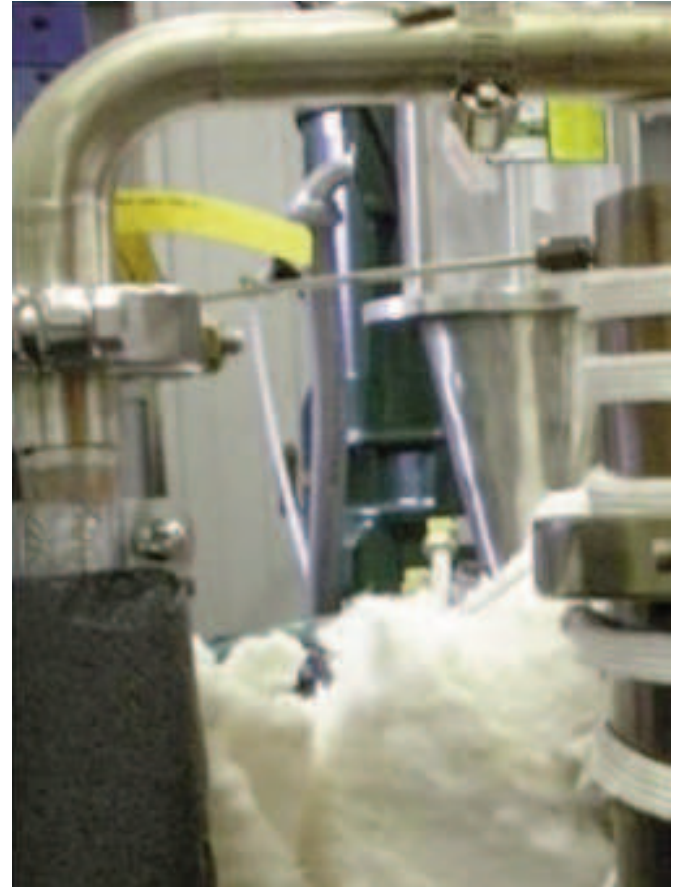

Figure A2: Char trap

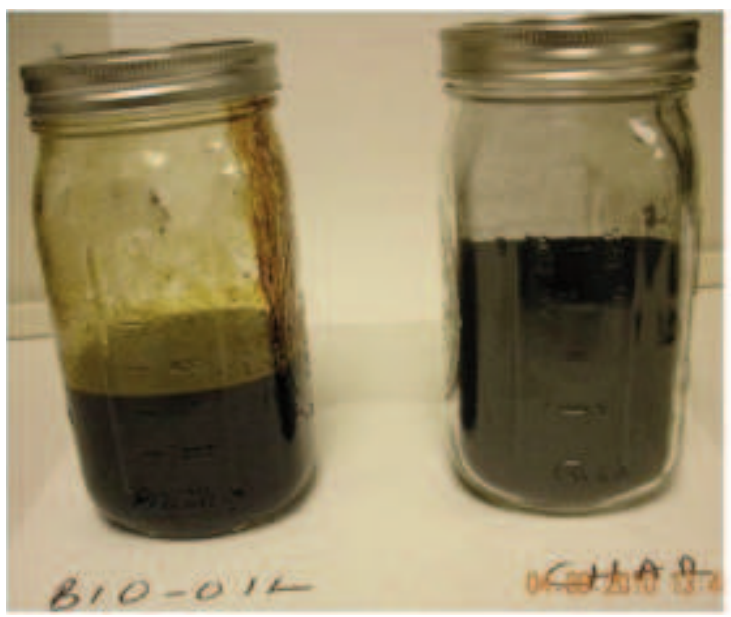

Figure A4: Bio-oil and bio-char

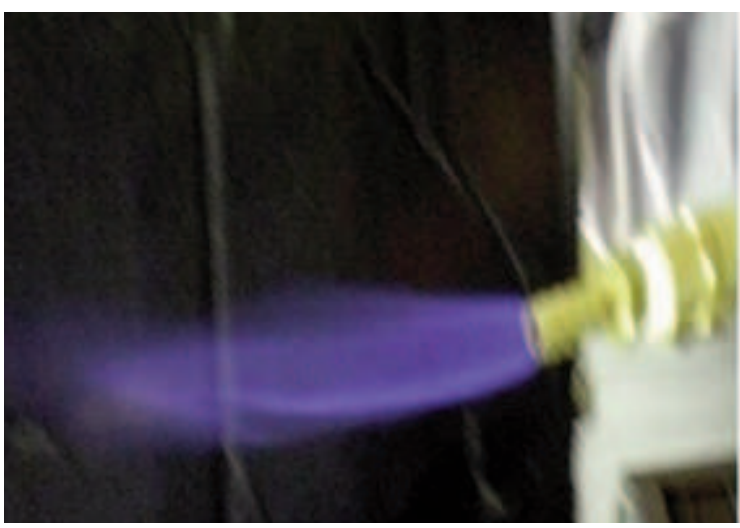

Figure A5: Combustibility test of NCG 